\title{
Assessing a community-based asthma education intervention
}

\author{
MM Vine ${ }^{1 *}$, SJ Elliott ${ }^{1}$, M Haynes $^{2}$, O Latycheva ${ }^{2}$, C Hampson $^{2}$ \\ From Canadian Society of Allergy and Clinical Immunology Annual Scientific Meeting 2009 \\ Halifax, Canada. 22-25 October 2009
}

Asthma prevalence has increased dramatically in western countries in the last 25 years, and it has been estimated that allergies and asthma affect 30 to $35 \%$ of the Canadian population. It has been generally estimated that there are approximately 714,000 Canadians diagnosed with chronic obstructive pulmonary disease (COPD), but it is also estimated that $50 \%$ of affected individuals remain undiagnosed, suggesting that there are over 1.4 million Canadians suffering from COPD. The literature has shown that asthma, associated allergies and COPD present tremendous social and health impacts for both individuals and communities; however, a recently piloted community-based asthma education program underscores how difficult it is to increase patient awareness and knowledge about asthma, associated allergies and COPD, improve early detection of these diseases, and therefore improve quality of life and overall chronic disease management. Quantitative surveys, along with asthma, allergy and COPD assessments (peak flow testing) were undertaken to ascertain participants' levels of asthma/COPD, knowledge of these diseases, and disease management strategies. Additional findings from a follow-up survey helped to confirm these findings. Overall, preliminary findings reveal that the pilot's success was limited. Barriers and facilitators to community-based asthma, allergy and COPD education and awareness, peak flow screening, and strategies to encourage proper chronic disease prevention and management, are discussed in this presentation.

Key Priority Areas

1- Chronic disease

2- Physical and built environment

3- Public health workforce development

\footnotetext{
* Correspondence: vinemm@mcmaster.ca

${ }^{1}$ School of Geography and Earth Sciences, McMaster University, Canada
}

\section{Author details}

'School of Geography and Earth Sciences, McMaster University, Canada

${ }^{2}$ The Asthma Society of Canada, Canada.

Published: 12 May 2010

doi:10.1186/1710-1492-6-S1-P9

Cite this article as: Vine et al:. Assessing a community-based asthma education intervention. Allergy, Asthma \& Clinical Immunology 20106 (Suppl 1):P9.
Submit your next manuscript to BioMed Central and take full advantage of:

- Convenient online submission

- Thorough peer review

- No space constraints or color figure charges

- Immediate publication on acceptance

- Inclusion in PubMed, CAS, Scopus and Google Scholar

- Research which is freely available for redistribution

Submit your manuscript at www.biomedcentral.com/submit
C Biomed Central 